\author{
N.G. Sidoryak*1, E.V. Rozova ${ }^{2}$ \\ ${ }^{1}$ Bohdan Khmelnitsky Melitopol State Pedagogical University, Melitopol, Ukraine; \\ ${ }^{2}$ Bogomoletz Institute of Physiology, National Academy of Sciences of Ukraine, Kyiv, Ukraine \\ *Corresponding author: eritrocit@ukr.net
}

\title{
Age peculiarities of the cardiovascular system and blood microcirculation in students under the influence of dosed physical training
}

\begin{abstract}
We investigated the adaptive capabilities of the cardiovascular system and blood microcirculation in 18-21-year-old students under the influence of dosed physical training. It was shown that there are significant age-related differences in the indicators of the cardiovascular system function at rest. By the 21-th year the majority of the studied parameters have reached the level characteristic of adult young men. After dosed physical training the indices of the cardiovascular system function increased to a greater or lesser extent, and the greatest increase was observed in 21 -year-old students. In younger age groups the changes were less effective, which characterizes the adaptive capabilities of the cardiovascular system depending on age. A marker indicator of the blood microcirculation system functioning - a microcirculation parameter that determines the direction of the microcirculation response to a dosed physical training - has been identified. It was found that among students of the 1st subgroup (low level of the microcirculation parameter) after physical activity it increased, and among students of the 2nd subgroup (high level of the microcirculation parameter) it mainly decreased, which characterizes the inclusion of various regulatory mechanisms in the blood microcirculation system. A decrease in the index of microcirculation efficiency under the influence of physical training was shown (the most significant in younger students). Such features can be explained by the lack of development of compensatory reactions in the microcirculation system.
\end{abstract}

Keywords: dosed physical training, microcirculation, blood pressure, Kerdo index, adaptive potential, heart rate, systolic volume, minute blood volume.

\section{Introduction}

At present more and more attention is paid to the issues of the influence of physical and psycho-emotional stress on the human organism. A special role is given to the period of study at the university, which is difficult and lengthy, requires emotional stability, increased energy consumption, and usually affects the age period, which coincides with the completion of puberty and the formation of homeostatic constants in the organism $[1,2]$. Adaptation to learning conditions is carried out by mobilizing of functional reserves and turning on most of the organism's regulatory systems. Dosed physical training (DPT) is capable of exerting a certain, usually adaptive, effect on the body, causing changes in the activity of a number of functional systems: respiration, blood and blood circulation. The most significant changes are observed in the cardiovascular system (CVS) [3], in particular, in such important component of its function as blood microcirculation in blood vessels $[4,5]$. In literature the problem of adaptation of the cardiovascular system, and especially blood microcirculation to DPT in students has not been sufficiently illuminated to date. The age aspect of this process is presented in an extremely fragmentary manner.

The aim of the study was to investigate the adaptive capabilities of the cardiovascular system and blood microcirculation in 18-21-year-old students under the dosed physical training.

\section{Materials and methods}

The investigations were carried out on 130 students of 18-21 years of natural-geographical faculty of the Bohdan Khmelnitsky Melitopol State Pedagogical University at rest and after DPT. Students were divided into 4 age groups: 18 years old -35 students, 19 years old -30 students, 20 years old -30 students, 21 years old - 35 students. Investigations with student's participation were carried out in accordance with the Council of Europe Convention "On protection of human rights and human dignity", considering the use in biology and medicine the Convention "On human rights and biomedicine" (№ 164 of 04.04.1997) and the Helsinki Declaration of the World Medical Association (2008).

The students' heart rate (HR) and blood pressure (BP) were determined using the KDTx-4 complex (Hungary); pulse pressure (PP), mean dynamic pressure (MDP), systolic volume (CV), minute blood volume 
(MBV) were calculated. Also, the Kerdo index (KI) and adaptive potential (AP) were determined. The last was calculated by the formula:

$$
\text { АП }=0.011 * \text { ЧСС }+0.014 * C А Д+0.008 * Д А Д+0.009 * M T-0.009 * P+0.014 * B-0.27 .
$$

DPT was modeled using a Biorhythm-4 bicycle ergometer and was selected in such a way that the work power provided the rate of $\mathrm{O}_{2}$ consumption at the level of 70-75\% of $\mathrm{VO}_{\max }$. For this the cadence for 2 minutes was 50-80 revs/min [5].

The study of blood microcirculation (MCC) was carried out by the method of laser Doppler flowmetry (LDF) using the LAKK-01 apparatus (Russia) $[6,7]$. The principle of the method is based on the reflection of a laser beam from moving blood particles (erythrocytes). The displayed signal encodes information about fluctuations in the flow of erythrocytes, both in terms of volumetric content and their speed [8].

The microcirculation parameter (PM), standard deviation (SD), coefficient of variation (Kv) were recorded, and the active and passive mechanisms of blood flow modulation were assessed. The LDF signal was measured on the ventral surface of the 4th finger of the left hand. The duration of the LDF-gram recording was 2 minutes [7].

\section{Statistics}

The results were statistically processed with help of the STATISTICA 6 software using the Student's $t$-test. The results are presented as the mean value \pm error of the mean $(\mathrm{M} \pm \mathrm{m})$, since, due to a significant array of digital material, as well as in accordance with the Shapiro-Wilk criterion, the obtained data fit into the normal distribution law [9]. Differences between the mean values were considered statistically significant at $\mathrm{P}<0.05$.

\section{Results and discussion}

The conducted research showed that HR among students of different ages at rest was significantly different; the highest value was observed in 18-year-old subjects. After performing DPT, this parameter increased in all age groups, most significantly in 19-year-olds - its value increased 1.8 times, which characterizes an adequate, but ineffective CVS response to DPT of a given intensity (Table 1).

$\mathrm{Table} 1$

Changes in some parameters of the cardiovascular system function in 18-21-year-old students before and after dosed physical training

\begin{tabular}{|c|c|c|c|c|c|}
\hline Characteristics & Survey period & 18 years & 19 years & 20 years & 21 years \\
\hline \multirow[t]{2}{*}{ Heart rate (beats/minute) } & Before & $70.8 \pm 1.12$ & $58.0 \pm 1.12 *$ & $63.7 \pm 0.99 *$ & $65.2 \pm 1.51$ \\
\hline & After & $123.8 \pm 2.24 * *$ & $106.0 \pm 2.61 * *$ & $107.9 \pm 4.2 * *$ & $103.6 \pm 1.58 * *$ \\
\hline \multirow{2}{*}{$\begin{array}{l}\text { Systolic pressure } \\
(\mathrm{mm} \mathrm{Hg})\end{array}$} & Before & $128.3 \pm 1.24$ & $121.7 \pm 0.31$ & $115.7 \pm 3.42$ & $138.9 \pm 2.15^{*}$ \\
\hline & After & $181.7 \pm 2.49 * *$ & $166.7 \pm 1.24 * *$ & $157.1 \pm 4.22 * *$ & $183.8 \pm 2.31 * *$ \\
\hline \multirow{2}{*}{$\begin{array}{l}\text { Diastolic pressure } \\
(\mathrm{mm} \mathrm{Hg})\end{array}$} & Before & $86.7 \pm 1.24$ & $81.7 \pm 0.31 *$ & $79.3 \pm 2.49$ & $93.6 \pm 2.10 *$ \\
\hline & After & $84.2 \pm 0.62$ & $81.6 \pm 0.32$ & $80.1 \pm 2.31$ & $83.2 \pm 1.84 * *$ \\
\hline \multirow{2}{*}{$\begin{array}{l}\text { Pulse pressure } \\
(\mathrm{mm} \mathrm{Hg})\end{array}$} & Before & $41.7 \pm 1.24$ & $40.0 \pm 0.15$ & $36.4 \pm 0.93$ & $44.2 \pm 0.98$ \\
\hline & After & $97.5 \pm 2.80 * *$ & $85.0 \pm 1.55^{* *}$ & $77.1 \pm 4.35^{* *}$ & $100.6 \pm 0.95 * *$ \\
\hline \multirow{2}{*}{$\begin{array}{l}\text { Mean dynamic pressure } \\
(\mathrm{mm} \mathrm{Hg})\end{array}$} & Before & $100.6 \pm 1.26$ & $95.0 \pm 0.31 *$ & $91.4 \pm 2.59$ & $108.3 \pm 1.98^{*}$ \\
\hline & After & $116.7 \pm 1.04 * *$ & $110.0 \pm 0.41 * *$ & $105.7 \pm 2.28 * *$ & $116.7 \pm 2.30 * *$ \\
\hline \multirow{2}{*}{$\begin{array}{l}\text { Systolic volume } \\
\text { (milliliters) }\end{array}$} & Before & $63.8 \pm 0.96$ & $65.0 \pm 0.15$ & $63.0 \pm 1.02$ & $60.4 \pm 1.68$ \\
\hline & After & $95.1 \pm 1.63 * *$ & $89.0 \pm 0.99 * *$ & $85.0 \pm 2.73 * *$ & $95.2 \pm 1.12 * *$ \\
\hline \multirow{2}{*}{$\begin{array}{l}\text { Minute blood volume } \\
\text { (liters) }\end{array}$} & Before & $4.83 \pm 0.61$ & $3.76 \pm 0.08^{*}$ & $4.02 \pm 0.09$ & $3.94 \pm 0.08$ \\
\hline & After & $11.8 \pm 0.041 * *$ & $9.52 \pm 0.33 * *$ & $9.17 \pm 0.63 * *$ & $9.86 \pm 0.09 * *$ \\
\hline
\end{tabular}

Notes. * - differences are significant between age groups (relative to the younger age group, $\mathrm{P}<0.05$ ); $* *-$ the differences are significant between the values of indicators before and after physical training $(\mathrm{P}<0.05)$.

In students the adaptation of HR to DPT depended on age and manifested itself as a stress reaction. As a rule, the release of stress hormones and the activation of the autonomic nervous system, aimed at the stabilizing of internal environment in the absence of adaptation of the organism to the physical activity were observed [1]. 
Indicators of systolic pressure (SP) underwent age-related fluctuations at rest: they decreased with age and, apparently, stabilized by the age of 21 at the level typical for healthy young men. Similar changes were observed in relation to diastolic pressure (DP) (Table 1).

After performing DPT an increase in SP was noted in all age groups. The greatest increase of this indicator was observed in 19-year-old students (1.4 times) and its value reached $166.7 \pm 1.24 \mathrm{~mm} \mathrm{Hg}$.

When analyzing changes in cardiac activity under the influence of DPT, we noted that in 18-year-old students it is due to an increase in HR by $75.2 \%$. It is usually considered as insufficient efficiency of cardiac activity regulation [10]. In 19-year-old students after DPT the observed changes in cardiac activity were to an even greater extent due to the predominance of chronotropic effects: the HR increased by $82.7 \%$. In 20 -yearold students the influence of chronotropic effects on cardiac activity after DPT slightly decreased: the HR increased only by $69.3 \%$, and in 21 -year-old students the HR increased by $58 \%$ (while the SP increased by slightly more than $40 \%$ ). Thus, it can be assumed that the efficiency of regulation of cardiac activity increases in students of older age groups. It can be concluded that the least efficiency of regulation in response to DPT occurs in the 19-year-old surveyed students.

The response of DP to DPT was manifested by a significant (by $11.1 \%$; P $<0.05$ ) decrease in 21-yearold students with unchanged indicators in other age groups. It is precisely this reaction from the side of blood pressure observed in older students that at present is considered adequate during physical activity [11]. In all age groups the increase in PP and MDP were noted, and significantly more pronounced relative to PP in persons aged 21 (Table 1 ).

An informative indicator of the hemodynamic function is the value of the systolic volume. Among the examined students its value differed depending on age, the highest value of SV was observed in 21-year-olds $(95.2 \pm 1.12 \mathrm{ml})$. After DPT the SV characteristics increased, but the rate of growth was different. The smallest shift was observed in 19-20-year-olds (by 36.9 and $34.9 \%$, respectively), the largest in 21-year-old students by $57.6 \%$ (Table 1). Hemodynamic changes of those in older age group followed a more effective path, mainly due to the volumetric rather than frequency component.

The value of the minute blood volume is determined by the need of organs and systems for oxygen. Comparing the values of MBV in the age aspect, it should be noted that at rest the differences had spasmodic character, however, only in 19-year-old students the value of MBV was significantly reduced, in the other groups the differences were in the form of a tendency (Fig. 1).

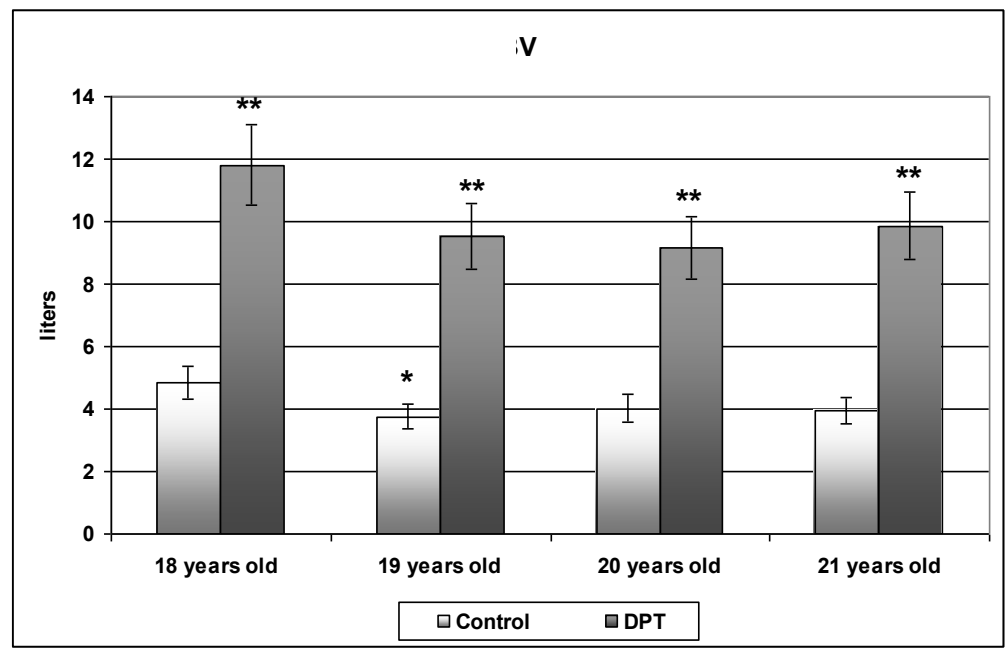

* - significant differences in control $-\mathrm{P}<0.05$,

** — reliability of differences from control values in DPT $-\mathrm{P}<0.01$

Figure 1. Age-related changes in minute volume of blood circulation (MBV) of the surveyed students

The MBV value after DPT increased in all age groups approximately equally from 2.3 to 2.5 times, depending on the age of the examined. It should be noted that the increase in this parameter after DPT, as indicated, was mainly due to the increase in HR, which points to a low efficiency of the heart, with its increase by the age of 21 , i.e., towards the end of puberty. 
Analyzing the changes in KI, we can judge the mechanisms of cardiac activity regulation. Thus, all students after performing DPT had sympathicotonia. The sympathetic nervous system plays a central role in the regulation of the CVS, therefore the predominance of the processes of activation and stimulation of physiological functions in the examined subjects can be stated, which is especially important under DPT [12]. The most pronounced sympathicotonia was observed in 18-year-old students.

The analysis of the adaptive potential (AP) among students showed that in the overwhelming majority of cases the AP level testified the unsatisfactory adaptation of the organism, which characterizes insufficient adaptability to physical activity. This is especially true for 18-year-old students, whose adaptive potential was 3.65. In older subjects (for example, a group of 20-year-olds) AP decreased to 3.15, which indicates the transition of the organism from the level of unsatisfactory adaptation to the level of functional tension of its mechanisms [13].

When analyzing the MCC in students on the basis of the conducted research, it was shown that, depending on the value of the main parameter of microcirculation (PM), it is necessary to divide each age group of the examined into 2 subgroups. Subgroup I consisted of students whose PM values ranged from 0.5 to 10 pf. units, in the subgroup II the PM ranged from 12 to 25 pf. units.

Comparing the value of PM in students of both subgroups in the age aspect, it can be noted that among students of subgroup I the highest value of PM was observed in 21-year-olds, and in subgroup II in 19-yearolds, which indicates a greater perfusion in this tissue area. After DPT students of subgroup I showed an increase in PM: the greatest increase was in 21-year-olds - 1.8 times, while in students of subgroup II this indicator decreased in 19-21-year-olds, with the exception of 18-year-old students. An increase in PM characterizes an improvement in perfusion in the probed area, and a decrease in PM indicates the relative impairment of perfusion (Fig. 2). Apparently, at high PM values the reserve capacity of tissue blood supply is reduced.

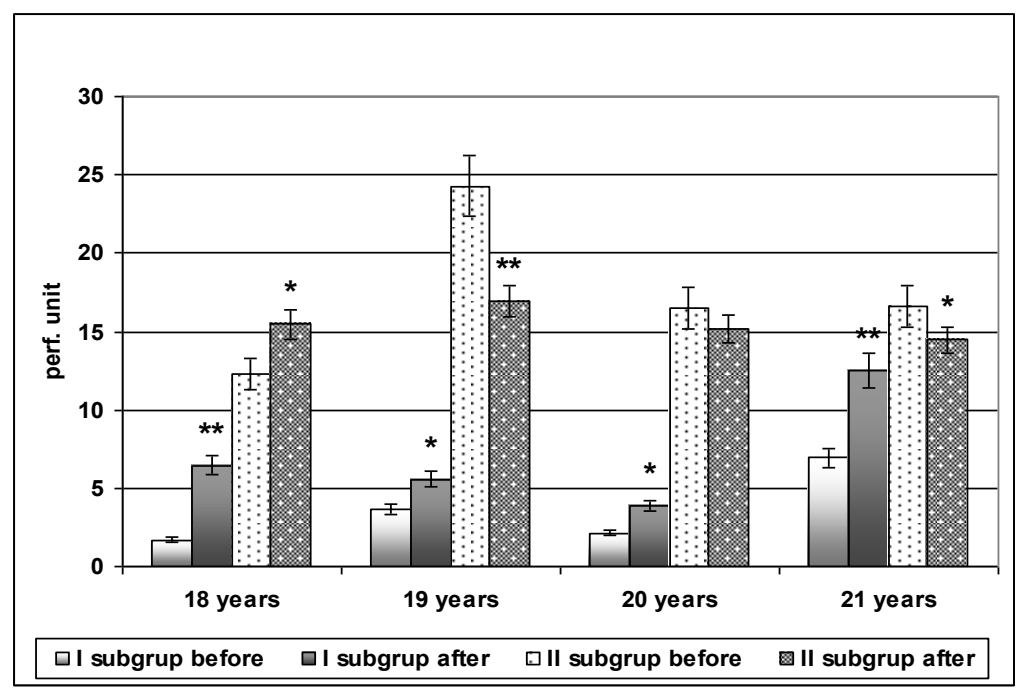

The reliability of changes in subgroups after exercise in relation to the control values: $*-\mathrm{P}<0.05$; ** $-\mathrm{P}<0.01$

Figure 2. Age-related changes in the microcirculation parameter (PM) in students at rest and after physical dosed load

The indicator of the standard deviation (SD), which characterizes the temporal variability of microcirculation, changed in the age aspect in students of both subgroups, smoothly increasing with age in students of the subgroup I and changing abruptly in the direction of increase in the students of the subgroup II (Fig. 3). After DPT in students of subgroup I it increased in 18-20-year-olds, which indicates an increasing of the MCC lability, while in the older age group its relative stabilization was observed. Students of subgroup II showed a decrease in SD, i.e., a decrease in the temporal variability of MCC in response to DPT (Fig. 3). 


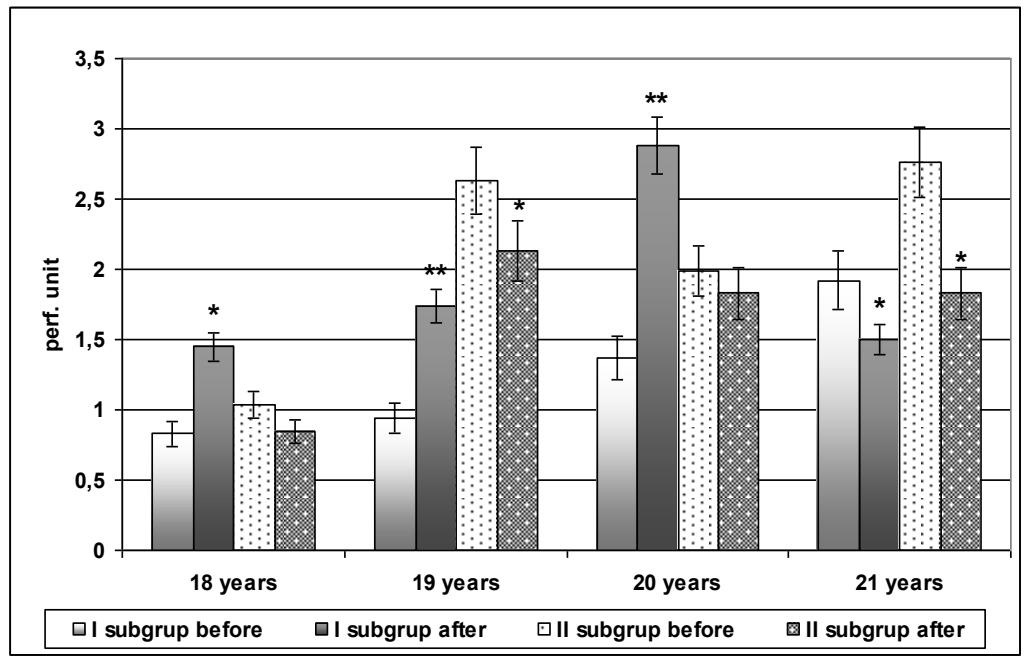

The reliability of changes in subgroups after exercise in relation to the control values: $*-\mathrm{P}<0.05 ; * *-\mathrm{P}<0.01$

Figure 3. Age-related changes in the indicator of the standard deviation (SD) of microcirculation in students at rest and after physical dosed training

There were also marked age-dependent changes in $\mathrm{Kv}$ among students of the subgroup I; the highest value was found in 18-year-olds (Fig. 4). In the second subgroup of students the differences in this indicator at rest were insignificant. After DPT the most pronounced deviations were observed in 18-year-olds of subgroup I - this indicator decreased. Since Kv characterizes the relationship between the variability of perfusion and the mean perfusion in the probed tissue site, thereby indicating the percentage contribution of active components to the total modulation of tissue blood flow, we can speak of an increase in the load on the vasomotor component of tissue blood flow modulation at a young age to ensure stable perfusion of the microvasculature.

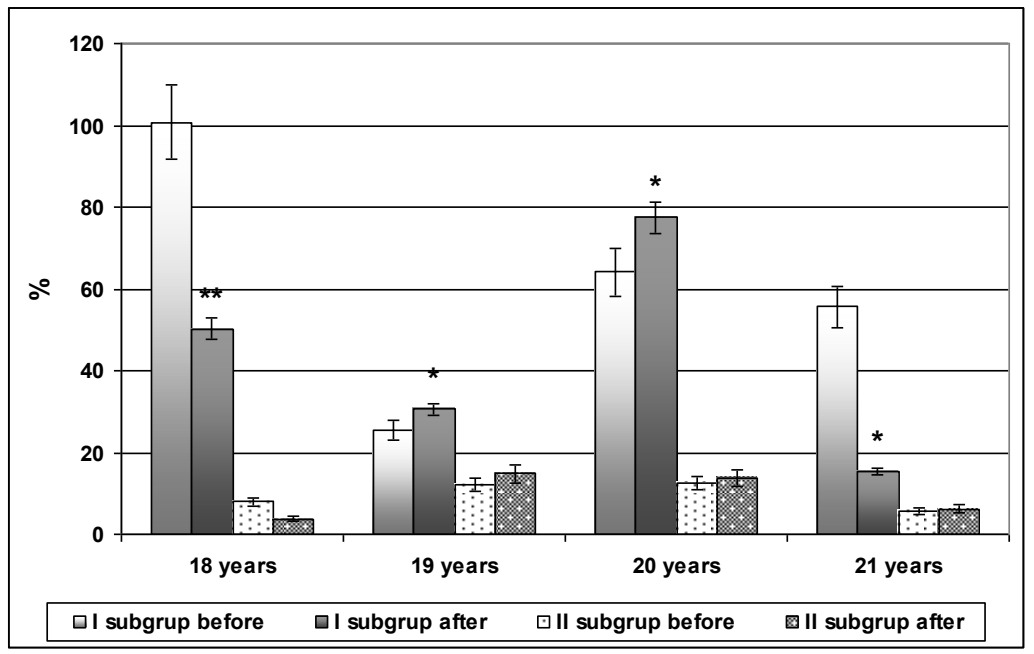

The reliability of changes in subgroups after exercise in relation to the control values: $*-\mathrm{P}<0.05 ; * *-\mathrm{P}<0.01$

Figure 4. Age-related changes in the indicator of the coefficient of variation $(\mathrm{Kv})$ among students at rest and after physical dosed training

The most important parameter characterizing the process of microcirculation is the index of the efficiency of microcirculation (IEM), since it characterizes the relationship between active and passive mechanisms of blood flow modulation in the MCC system.

When analyzing this parameter among students in the age aspect, both in subgroup I and in subgroup II, IEM increases with age (with a maximum in 19-year-olds from subgroup I). Influence of DPT has a lowering 
effect on this index in all age groups of both subgroups. The greatest decrease in IEM was observed in 19-yearold students of the subgroup I (Fig. 5).

The decrease of IEM in students of both subgroups in response to physical activity can be explained by the lack of compensatory mechanisms development, especially in younger age groups.

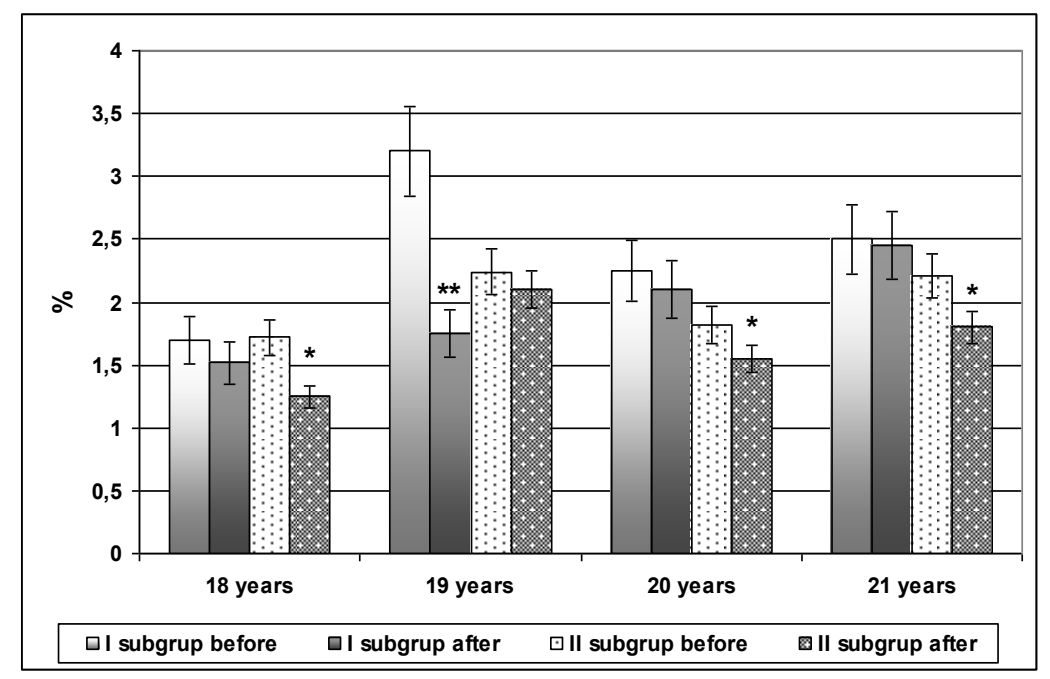

The reliability of changes in subgroups after exercise in relation to the control values: $*-\mathrm{P}<0.05 ; * *-\mathrm{P}<0.01$

Figure 5. Age-related changes in the index of the efficiency of microcirculation (IEM) among students at rest and after physical dosed training

\section{Conclusion}

Despite the insignificant age differences between the groups of students, the indices of the cardiovascular system function (HR, SP, DP, SV, MBV) at rest significantly differed depending on age. By the age of 21 most of the studied parameters (either decreasing or increasing in waves) reached the level typical for young adult men.

After physical training these indicators increased to a greater or lesser extent, and the most pronounced increase was observed in 21-year-old students. In younger age groups the changes were less effective, which additionally indicates an insufficient level of the adaptive potential of their organism.

Such features must be taken into account when planning the training process of students in physical training classes. Moreover, in parallel, a decrease in the index of microcirculation efficiency under the influence of physical training (also the most significant in younger students) was shown. The degree of this decrease depended on the initial level of the microcirculation parameter, i.e., on the intensity of tissue blood supply. Such features can be explained by the lack of development of compensatory mechanisms in the blood microcirculation system.

\section{References}

1 Абишева 3.С. Изменение сердечно-сосудистой системы в покое / З.С. Абишева, У.Б. Искакова, Г.Д. Жеписбаева, Г.К. Асан, М.С. Журунова, Г.К. Раисов, Т.М. Исмагулова, М.Б. Даутова // Междунар. журн. прикл. и фунд. иссл. - 2016. № 1-4. - С. 510-512.

2 Агаджанян Н.А. Стресс и теория адаптации / Н.А. Агаджанян. - Оренбург: ИПК ГОУ ОГУ, 2005. — 190 с.

3 Геворкян Э.С. Морфологические показатели как критерии оценки студентов к дозированной физической нагрузке / Э.С. Геворкян, Ц.Й. Адамян, Г.Г. Туманян // Гигиена и санитария. — 2010. — № 2. — С. 75-77.

4 Розова Е.В. Особенности микроциркуляции крови, морфофункционального состояния капилляров и митохондрий в мышечной ткани при дозированной физической нагрузке / Е.В. Розова, Е.Р. Тимошенко, Н.Г. Сидоряк // Україн. журн. мед., біол. та спорту. — 2018. - № 3. - С. 199-205. 
5 Sidoryak N.G. Age changes of blood microcirculation in students and sportsmen under the influence of physical training / N.G. Sidoryak, E.R. Timoshenko, M.V. Belikova, E.V. Rozova // East European Scientific Journal Wschodnioeuropejskie Czasopismo Naukowe. - 2017. - Vol. 1, No. 9. - P. 5-12.

6 Бархатов И.В. Оценка системы микроциркуляции крови методом лазерной допплеровской флуометрии / И.В. Бархатов // Клин. мед. - 2013. - № 11. - С. 21-27.

7 Козлов В.И. Инструкция по применению лазерного анализатора капиллярного кровотока ЛАКК-01 / В.И. Козлов, Э.С. Мач, В.В. Сидоров. - М., 2000. - 196 с.

8 Bollinger A. Is high - frequency flux motion due respiration or to vasomotion activity? Invasomotion and blom motion / A. Bollinger, A. Yanar, U. Hoffmann, U.K. Franzeek // Prog. Appe Microcilcue Bagel. — 1993. — No. 20. — P. 52-58.

9 Лукьянова Е.М. Методика статистической обработки медицинской информации в научных исследованиях / Е.М. Лукьянова, Ю.Г. Антипкин, В.П. Чернышов, Е.В. Выхованец. — Киев: Планета людей, 2002. — 200 с.

10 Детков Ю.Л. Теория и практика физической культуры для студентов с ослабленным здоровьем / Ю.Л. Детков, B.А. Платонова, Е.В. Зефирова. [Электронный ресурс]. Режим доступа: $2016 . \quad$ - http://window.edu.ru/cata$\log /$ pdf2txt $/ 364 / 60364 / 30311$ ? p_page $=9$

11 Fletcher G.F. Exercise standards for testing and training: a scientific statement from the American Heart Association / G.F. Fletcher, P.A. Ades, P. Kligfield, R. Arena, G.J. Balady, V.A. Bittner // Circulation. — 2013. — Vol. 128, No. 8. — P. 873-934.

12 Bruno R.M. Sympathetic regulation of vascular function in health and disease [Electronic resource] / R.M. Bruno, L. Ghiadoni, G. Seravalle, R. Dell'Oro, S. Taddei // Physiol. — 2012. Access mode: https://doi.org/10.3389/fphys.2012.00284

13 Цинкер В.М. Оценка адаптационного потенциала организма спортсменов на различных этапах спортивной тренировки / В.М. Цинкер, Д.В. Дугарова // Вестн. ВБГУ. — 2011. — № 13. — С. 159-162.

\author{
Н.Г. Сидоряк, Е.В. Розова
}

\title{
Дозаланған физикалық белсенділіктің әсерінен студенттердегі жүрек-қантамыр жүйесі реакциясы мен қан микроциркуляциясының жас ерекшеліктері
}

\begin{abstract}
Дозаланған физикалық белсенділіктің әсерінен 18-21 жастағы студенттердегі жүрек-қан тамырлары жүйесінің және қанның микроциркуляциясының адаптивті мүмкіндіктері зерттелген. Тыныштык жағдайында жүрек-қантамыр жүйесінің қызметі көрсеткіштерінде жасқа байланысты айтарлықтай айырмашылықтар бар екендігі көрсетілген. 21 жасқа қарай зерттелген индикаторлардың көпшілігі ересек ерлерге тән деңгейге жетті. Дозаланған физикалық жүктемеден кейін жүрек-қан тамырлары жүйесінің көрсеткіштері азды-көпті өсті, ал ең үлкен өсім 21 жастағы студенттерде байқалды. Жас топтарда өзгерістер аз болды, бұл жасқа байланысты жүрек-қан тамырлары жүйесінің бейімделу мүмкіндіктерін көрсетеді. Қанның микроциркуляция жүйесінің жұмысының маркер индикаторы дозаланған физикалық жүктемеге микроциркуляция реакциясының бағытын анықтайтын микроциркуляция параметрі бөлінді. І-ші шағын топтың студенттері арасында (параметрдің төмен деңгейі) дене жаттығуларынан кейін оның жоғарылағаны анықталды, ал 2-ші шағын топтың студенттерінде (параметрдің жоғары деңгейі) негізінен төмендеді, бұл әртүрлі реттеу механизмін енгізуді сипаттайтын қанның микроциркуляция жүйесі. Физикалық белсенділіктің әсерінен микроциркуляция тиімділігі индексінің төмендеуі байқалды (ең маңыздысы жас оқушыларда). Мұндай ерекшеліктерді микроциркуляция жүйесінде компенсаторлық реакциялардың дамымауымен түсіндіруге болады.
\end{abstract}

Кілт сөздер: дозаланған дене белсенділігі, микроциркуляция, қан қысымы, Кердо индексі, бейімделу потенциалы, жүрек соғысы, систолалық көлем, қанның минуттық көлемі.

\author{
Н.Г. Сидоряк, Е.В. Розова
}

\section{Возрастные особенности реакции сердечно-сосудистой системы и микроциркуляции крови у студентов под влиянием дозированной физической нагрузки}

Исследовали адаптационные возможности сердечно-сосудистой системы и микроциркуляции крови у 18-21-летних студентов под влиянием дозированной физической нагрузки. Показано наличие существенных возрастных различий показателей функции сердечно-сосудистой системы в состоянии покоя. К 21-му году большинство изучаемых показателей достигали уровня, свойственного взрослым молодым мужчинам. После дозированной физической нагрузки показатели функции сердечно-сосудистой системы в большей или меньшей степени возрастали, причем наибольший прирост отмечался у 21 -летних студентов. В младших возрастных группах изменения носили менее эффективный характер, что 
свидетельствует об адаптационных возможностях сердечно-сосудистой системы, зависящих от возраста. Выделен маркерный показатель функционирования системы микроциркуляции крови - параметр микроциркуляции, определяющий направленность реакции микроциркуляции на дозированную физическую нагрузку. Установлено, что у студентов I подгруппы (низкий уровень параметра) после физической нагрузки он увеличивался, а у студентов II подгруппы (высокий уровень параметра) преимущественно уменьшался, что характеризует включение различных механизмов регуляции в системе микроциркуляции крови. Показано снижение индекса эффективности микроциркуляции под влиянием физической нагрузки (наиболее существенное у младших студентов). Такие особенности можно объяснить недостаточностью развития компенсаторных реакций в системе микроциркуляции.

Ключевые слова: дозированная физическая нагрузка, микроциркуляция, артериальное давление, индекс Кердо, адаптационный потенциал, частота сердечных сокращений, систолический объем, минутный объем крови.

\section{References}

1 Abisheva, Z.S., Iskakova, U.B., Zhepisbaeva, G.D., Asan, G.K., Zhurunov, M.S., \& Raisov, G.K., et al. (2016). Izmenenie serdechno-sosudistoi sistemy v pokoe [Change in the cardiovascular system at rest]. Mezhdunarodnyi zhurnal prikladnykh i fundamentalnykh issledovanii - International Journal of Applied and Fundamental Research, 1-4; 510-512 [in Russian].

2 Agadzhanyan, N.A. (2005). Stress i teoriia adaptatsii [Stress and adaptation theory]. Orenburg: IPK GOU OSU [in Russian].

3 Gevorkyan, E.S., Adamyan, Ts.Y., \& Tumanyan, G.G. (2010). Morfologicheskie pokazateli kak kriterii otsenki studentov k dozirovannoi fizicheskoi nagruzke [Morphological indicators as criteria for assessing students to dosed physical activity]. Gigiena $i$ sanitariia - Hygiene and Sanitation, 2; 75-77 [in Russian].

4 Rozova, E.V., Timoshenko, E.R., \& Sidoryak, N.G. (2018). Osobennosti mikrotsirkuliatsii krovi, morfofunktsionalnogo sostoianiia kapilliarov i mitokhondrii v myshechnoi tkani pri dozirovannoi fizicheskoi nagruzke [Features of blood microcirculation, morphofunctional state of capillaries and mitochondria in muscle tissue during dosed physical activity]. Ukrainskii zhurnal meditsini, biologii ta sportu - Ukrainian Journal of Medicine, Biology and Sports, 3; 199-205 [in Russian].

5 Sidoryak, N.G., Timoshenko, E.R., Belikova, M.V., \& Rozova, E.V. (2017). Age changes of blood microcirculation in students and sportsmen under the influence of physical training. East European Scientific Journal Wschodnioeuropejskie Czasopismo Naukowe, $1(9) ; 5-12$.

6 Barkhatov, I.V. (2013). Otsenka sistemy mikrotsirkuliatsii krovi metodom lazernoi dopplerovskoi fluometrii [Evaluation of the blood microcirculation system by laser Doppler fluometry]. Klinicheskaia meditsina - Clinical medicine, 11; 21-27 [in Russian].

7 Kozlov, V.I., Mach, E.S., \& Sidorov, V.V. (2000). Instruktsiia po primeneniiu lazernogo analizatora kapilliarnogo krovotoka LAKK-01 [Instructions for use of the laser analyzer of capillary blood flow LAKK-01]. Moscow [in Russian].

8 Bollinger, A., Yanar, A., Hoffmann, U., \& Franzeek, U.K. (1993). Is high — frequency flux motion due respiration or to vasomotion activity? Invasomotion and blom motion. Prog. Appe Microcilcue Bagel, 20; 52-58.

9 Lukyanova, E.M., Antipkin, Yu.G., Chernyshov, V.P., \& Vykhovanets, E.V. (2002). Metodika statisticheskoi obrabotki meditsinskoi informatsii $v$ nauchnykh issledovaniiakh [Methods of statistical processing of medical information in scientific research]. Kiev: Planeta liudei [in Russian].

10 Detkov, Yu.L., Platonova, V.A., \& Zefirova, E.V. (2016). Teoriia i praktika fizicheskoi kultury dlia studentov s oslablennym zdorovem [Theory and practice of physical culture for students with impaired health]. window.edu.ru Retrieved from: http://window.edu.ru/catalog/pdf2txt/364/60364/30311? p_page=9 [in Russian].

11 Fletcher, G.F., Ades, P.A., Kligfield, P., Arena, R., Balady, G.J., \& Bittner, V.A. (2013). Exercise standards for testing and training: a scientific statement from the American Heart Association. Circulation, 128 (8); 873-934.

12 Bruno, R.M., Ghiadoni, L., Seravalle, G., Dell'Oro, R., \& Taddei, S. (2012). Sympathetic regulation of vascular function in health and disease. Physiol. Retrieved from: https://doi.org/10.3389/fphys.2012.00284

13 Tsinker, V.M. \& Dugarova, D.V. (2011). Otsenka adaptatsionnogo potentsiala organizma sportsmenov na razlichnykh etapakh sportivnoi trenirovki [Assessment of the adaptive potential of the organism of athletes at different stages of sports training]. Vestnik VBSU - Bulletin of VBSU, 13; 159-162 [in Russian]. 